\title{
EL IDIOMA MATERNO: LA IMPORTANCIA LIBERTARIA DEL SIGNIFICANTE CONVERTIDO EN LIBRO
}

\author{
María Esther Castillo García \\ (Universidad Autónoma de Querétaro)
}

“... desde pequeño, mi relación con las palabras, con la escritura, no se diferencia de mi relación con el mundo en general.

Yo parezco haber nacido para no aceptar las cosas tal como me son dadas"

Julio Cortázar

"Hay que buscar, buscar incesantemente aquello de lo cual todo cuanto decimos es solo traducción"

Paul Valéry

\section{Introducción}

El idioma materno [2014] ${ }^{1}$ del escritor ítalo-mexicano Fabio Morábito es una antología de ochenta y cuatro ensayos breves escritos en primera persona, en cada uno se enuncia y describe la pasión, el talento y el trabajo contenido en toda su producción. El trazo del autor en el texto revela al menos dos instancias fundamentales, el trayecto de vida literaria ante la necesidad o el destino de ser escritor y la problemática centrada en la palabra [el significante] como la materia prima y el fundamento de su oficio; es como si en la palabra comenzara una fortaleza que puede ser aún mayor que su sentido. Esta forma de interpelación, que se reitera a lo largo del libro, puede ejemplificarse a través de un fragmento del último ensayo:

${ }^{1}$ Todas las citas del libro, salvo se indique lo contrario, corresponden a: Fabio Morábito: El idioma materno. Cd. de México: Sexto Piso, 2014. 


\begin{abstract}
"El idioma materno":
Es un hueso duro de roer. Cuando se cree que por fin nos liberamos de sus palabras, sus giros sintácticos, sus modismos intraducibles a otros idiomas, y que después de tantos años de hablar, soñar, amar e injuriar en otra lengua, uno se ha emancipado de su atadura, resulta que esas calcificaciones de materia marina que se adhieren al cuerpo de las ballenas y que asemejan enormes quistes, el viejo idioma no ha desaparecido, sólo se ha replegado en ciertas zonas, una de las cuales, quizá la más resistente es el Ilanto. [177]
\end{abstract}

La inscripción se valida a manera de paráfrasis y constituye el prólogo o el epílogo que transparenta en la imagen, 'hueso duro de roer', la fuerza, la resistencia, incluso la crisis en la permanencia del signo, de las palabras que se remiten unas a otras en el intento de hurgar la férrea resistencia del idioma materno. En esta búsqueda hay un riesgo implícito en su proximidad ante el significado y el sentido de la palabra, porque igual procede del reservorio memorioso como de la palabra emancipada en el cruce de las coordenadas históricas; en este cruce, además, cuentan los significados y sentidos provenientes de un sólido legado literario.

Morábito selecciona y comunica a través de los breves ensayos el corpus literario que le interesa, nombra algunos textos de cabecera (El extranjero de Albert Camus, Esperando a Godot de Samuel Becket), ciertos tonos y ambientes (las voces de Ana Karenina, la profundidad poética de César Vallejo, la elección nominativa de Kafka, los diálogos de Dostoievski), además de anécdotas simples y microrrelatos. Cada alusión sugiere el tipo de influencia estilística que prefigura una biblioteca personal en donde arbitran los gustos del autor. La relación de lecturas estimadas, de métodos disciplinarios, de mitos, manías e influencias, que Morábito nos comparte, y que clasificamos de "ensayos de autor" es una práctica que muchos artistas reconocen.

Esta subclasificación delimita un proyecto de escritura más personal. Tarde o temprano, muchos escritores reúnen y muestran que el oficio de escribir tiene razón de ser. Quizás como afirma Francesco Piccolo en Escribir es un tic [2008] este tipo de "testimonio" sea un modo

\footnotetext{
de justificar el hecho de encerrarme en un cuarto durante horas y horas todos los días; demostrar que hacía exactamente lo mismo que todos los demás, era otro modo de ahuyentar la sospecha de que me estaba equivocando [...] un modo de hacer patentes mis deseos incluso ante quienes no tenían la menor idea de lo que es el afán de escribir. [12]
} 
La facilidad o la dificultad de decir "yo", de autentificar o de justificar el ansia de descubrir ante sí mismo y ante los demás su propio reflejo en el espejo, quizás encuentra en la forma ensayística el género idóneo para afirmar que en la vida y en la obra, lo deseado, creído o experimentado, no siempre marcha al ritmo del pensamiento, de que la razón crítica lidia con los apegos, el imaginario, los furores, las manías, de que las reflexiones colisionan contra el oficio vital e íntimo de su escritura. Marcelo Percia en El ensayo como clínica de la subjetividad [2001], afirma que gran parte de los 'ensayos de autor' pueden leerse como "terapéuticas de palabras que fracasan. Como escrituras que se duelen por decir lo que no pueden decir" [10], por consiguiente, no es casual que "las preguntas sobre subjetividad agradecen las formas del ensayo" [10]. Tales formas pueden resplandecer como escrituras afirmativas $y$, al contrario, como postulaciones escépticas frente al saber y al imaginario. $Y$ esto probablemente sea así desde la época ilustrada (Montaigne, Rousseau) hasta tiempos posteriores (Sartre, Blanchot, Barthes, entre otros). En nuestra época se afirma que "lo ensayístico se lo ha identificado como el punto de irrupción de aquello que llamamos de distintas maneras: del yo, del sujeto, de la subjetividad" [Kuri 2001:104]. En cada expresión ensayística, se enuncie o se evada ésta, la intencionalidad y procedencia ideológica autentifica la identidad del sujeto que se construye en el tránsito de la escritura. Habría que considerar que el 'ensayo de autor' no se confunde con la autobiografía, pues, aunque se escriba en primera persona (porque es instancia del sujeto y no asunto subjetivo) y contenga reflexiones en donde resuenan los motivos centrales sobre la comprensión del yo.

La lista de escritores que, como dijese el argentino Juan José Saer, gustan de narrar la incertidumbre y traducen su obra ficcional en un ensayo [1993] ha gozado de larga vida y solidez. Mencionamos a continuación algunos nombres de artistas mexicanos atentos a la premisa de una modernidad, que consideraba que la palabra en el ensayo había mostrado plena distancia de la palabra total en el sentido de que la interpretación había sustituido a la explicación. Se puede corroborar tal característica en los ensayos de Alfonso Reyes (La experiencia literaria 1962) o de Octavio Paz (La llama doble 1993), cuya actitud crítica y poética se conjuga en el mismo texto; más adelante, en los escritores de la generación del medio siglo, principalmente en Juan García Ponce (Tres voces 2000), Julieta Campos (Razones y pasiones 2005) y Salvador Elizondo (Teoría del infierno 2000), el ensayo se convierte en una forma entre poética y argumentativa que podía o no dar cuenta de la interpretación de las cosas públicas y discutir sobre intereses estéticos desde miradas íntimas. En los ensayos de dicha generación, el autor permanece atento a la propia reflexión artística de su 
escritura, comunicándola con una elocuencia autorreferencial, metadiscursiva y metatextual. Entre los escritores contemporáneos a Morábito² y que manejan un tipo de retórica persuasiva hacia la aceptación de una escritura que borra las fronteras entre el ensayo y la ficción, incluso la performance del lenguaje verbal y corporal virtual, se encuentra un ejemplo rotundo en Mario Bellatin (Los cien mil libros de Bellatin 2014), en cuyas obras el ensayo y la ficción circulan sobre el sí mismo y el ejercicio escriturario, Morábito coincidiría con escritores como Guillermo Fadanelli (Insolencia -literatura y mundo 2012), que al tratar de incluir en sus ensayos la realidad como reacción social, la vuelve autotestimonial. Podríamos conjeturar que en la vastedad de intenciones críticas y creativas de los 'ensayos de autor', no sólo rige la forma reflexiva y la sofisticación interpretativa y crítica del género sino la repercusión autocrítica y solipsista.

\section{Subjetividad e identidad en el ensayo de autor}

Marcelo Percia en El ensayo como clínica de la subjetividad, sugiere, que en los 'ensayos de autor', "la relación entre ensayística y subjetiva es tensa, contradictoria, apasionada" [11], que al inquirir sobre la escritura a los propios escritores y lectores se pone en escena una serie de "contactos intangibles entre palabra y vida, pensamiento y dolor, forma y deseo" [11], provocando "inquietud y fastidio". Las opiniones sobre la subjetividad en el ensayo pueden documentar tanto lo escurridizo o indeterminado de los pensamientos del autor plasmados en sus obras como las preguntas sobre si el acto de escribir responde a una vocación, si demanda un oficio solitario, o si acaso la escritura es sólo reescritura mutante. Pedro Orgambide en "Un escritor frente a su escritura" [2001], describe su propio trayecto y persistencia en el ensayo con el ánimo de "mirarse desde y frente a su propia escritura, desde y frente a sus propios medios y perplejidades, en el camino apasionante y arduo de transformar en palabras intuiciones acerca de uno mismo y del mundo que le toca en suerte" [45]. Liliana Weinberg, en El ensayo, entre el paraíso y el infierno [2001], incluye un comentario que creemos empata con la indagatoria de Morábito: "la palabra va en busca de la palabra, ya en pos de la restitución creadora del sentido perdido, ya en pos de una agudización cada vez más profunda de la crítica, ya en pos de una expansión de los procesos de sentido a través de la interpretación" [94].

\footnotetext{
${ }^{2}$ No incluimos la extensa lista de autores cuya trayectoria enriquece la tradición mexicana sobre el ensayo. Sólo mencionamos a dos autores que comparten la misma generación de Morábito.
} 
Por nuestra parte lectora, no descartamos que hay un placer morboso por "descubrir" por qué los escritores "se afanan en explicar la parte normal de su trabajo y tienen que defenderse de la mítica: porque en realidad es toda falsa" [Francesco Piccolo, 2008:12].

Este tipo de sugerencias sobre los 'ensayos de autor' (y de su ensayística) despierta el interés en su lectura. El qué, cómo, cuándo y por qué escribir sobre las inquietudes y los trabajos que la palabra genera como ejercicio escriturario y literario parece ineludible tanto para los artistas como para sus ávidos lectores.

En El idioma materno, hemos afirmado, Morábito hace de la palabra el sustento, el objeto que se persigue tras una serie de conjeturas que redundan en el cuestionamiento de la creación. Cada ensayo de la antología, paradójicamente quizá, se libera del otro para agregar sentido, como si se tratara de capas superpuestas de un todo inteligible en busca de la restitución idiomática o "palabrera" en la totalidad de su obra. En este acto de restitución y de expansión [Weinberg] la identidad oficial interviene, convengamos en el hecho de que la doble nacionalidad del autor y las varias mudanzas de un país al otro contienden en la formación del sujeto escritor que autentifica su propio yo.

Observemos las señas biobibliográficas: Morábito nació en Alejandría [Egipto] en 1955, de padres italianos. A los tres años ya está en Italia, su infancia transcurre en Milán y a los quince años la familia completa emigra a México; desde entonces vive aquí, escribe y publica toda su obra no en italiano, el idioma materno, sino en español. En este idioma ha escrito libros de poesía, el más reciente Delante de un prado una vaca [2011]. El anterior se titula La ola que regresa [2006] y reúne otros tres: Lotes baldíos, De lunes todo el año, Alguien de lava. En cuanto a sus libros de cuentos destacan La lenta furia [1989], Eterna cadencia [2010], La vida ordenada [2000] y Grieta de fatiga [2006]. Es autor de otros volúmenes ensayísticos como Caja de herramientas [1989], Los pastores sin ovejas [1995] y También Berlín se olvida [2015] y ha publicado la novela: Emilio, los chistes y la muerte [2009]. Muchos de sus libros han sido traducidos al italiano, francés, portugués e inglés.

Estas señas identitarias también alimentan el decir de la crítica que difunde su obra. Lo más notorio es la admiración que su lenguaje congrega, de hecho, la periodista Jéssica Zambrano advierte esta característica respaldada por un comentario de Sergio Pitol, él subraya esa fascinación por las palabras: 
Morábito se reveló desde sus iniciales ejercicios literarios como uno de los raros de la lengua. Desconcertó a algunos y fascinó a otros cuantos. Quien pretenda imitarlo se arriesga a cometer un suicidio. Su prosa elegante y exquisita es irrepetible. Nada de pomposo se acerca a su mundo. Parecería que sus palabras, precisas y transparentes, le sirvieran como un encantamiento, un regalo, un guiño a los lectores. Pero en el subsuelo se encuentra una lava ardiente, un nudo de interrogaciones e hipótesis cercanas a una metafísica. [Zambrano: s/p]

La opinión de Pitol $^{3}$ coincide con la de otros críticos que identifican en su discurso una cierta 'rareza' o 'singularidad' en la arbitrariedad de los signos, tanto en las voces narrativas como en las líricas4. Morábito mismo dice aplicar un "patrullaje sigiloso" [2014:15] a la hora de proponer imágenes retóricas que preceden e interceptan el idioma adquirido y la lengua materna. También ha declarado en diversas ocasiones que "el italiano y el español son como dos gemelos, que se llevan bien pero que en el fondo nunca terminan de entenderse ${ }^{\prime \prime}$.

Entre la premisa del idioma materno como un tácito rasgo identitario [desde el título] y la mirada personal que filtra los preceptos teóricos de qué, cómo y por qué escribir, no hay una narración de la historia personal ni de lo vivido en sentido estricto, como requiere una autobiografía. Morábito se muestra incluso evasivo ante lo biográfico, sin menoscabo de los escrúpulos y vacilaciones idiomáticas que forman parte de su escritura:

\begin{abstract}
El yo profundo jamás despertará del todo y, si lo hace, es probable que no tenga nada relevante. En todo escritor hay un yo así genuino e infeliz, incapaz de algo digno de nota. Uno se hace escritor el día que encuentra un yo postizo que viaja modestamente en el carril de acotamiento para no despertar al otro, el que ocupa el carril central. Hacerse escritor es deslizarse hacia el borde, volverse un tanto anónimo y escurridizo, menos genuino y profundo, que es el precio principal que hay que pagar en este oficio. [140]
\end{abstract}

En este ajuste entre el rigor y la subjetividad que nivela el ensayo, la coyuntura idiomática centrada en las palabras es un legado que el escritor debe atender por igual entre la coexistencia y la oposición de reglas "implacablemente hostiles", como sugiriese Maurice Blanchot [2006:27]

\footnotetext{
${ }^{3}$ Pitol es uno de los tantos escritores cuyas escrituras presentan un hibridismo entre la novela y el ensayo. El mago de viena [2006], por ejemplo, puede parecer un conjunto de ensayos literarios en donde el narrador hace constantes comentarios sobre libros y autores, reflexiona sobre la creación literaria, la importancia de la lectura, la interpretación y traducción. No es casual que a Pitol le interese comentar la obra de Morábito que muestra objetivos y poéticas semejantes.

${ }^{4}$ Cfr. en comentarios y entrevistas y disertaciones, por ejemplo: Jezreel Salazar : "Fabio Morábito, un ethos autobiográfico" http://senalc.com/2015/11/15/fabio-morabito-un-ethos-autobiografico/. En: "Fabio Morábito: La patria del lenguaje": www. correodellibro.com.mx/entrevista/fabio-morabito-la-patria-del-lenguaje/. En Fabiene Bradu: "Grieta de fatiga de Fabio Morábito", Letras Libres, 31/05/2006. En Fabiola Fernández: "Fabio Morábito: Poéticas del vaivén. Extranjería, lengua y memoria". Disertación, Universidad de São Paulo Facultad de filosofía, letras e ciencias humanas, Departamento de letras modernas. Programa de Posgraduados en Lengua Española y Literaturas española e hispano-americana, versión PDF, 2014

${ }^{5}$ La frase proviene de una entrevista sin autoría: "Escribir como un correctivo. Charlando con Fabio Morábito", en línea <iletradoperocuerdo.com/2014/10/02/escribir-como-un-correctivo-charlando-con-fabio-morabito/>.
} 
al estudiar la escritura de Kafka. Blanchot consideraba a la palabra como esa espiral que reúne simultáneamente la afirmación y la negación en la inestabilidad de una página en blanco. En este tenor de la página en blanco y del primer trazo de tinta en la fragmentación continuada de un ensayo, también ubicaríamos una ruta de resistencia entre las cosas de la vida y las ideas, la comprensión y las inferencias múltiples que provoca entender si la escritura tiende hacia el "idioma materno" como un centro o si surge de éste.

Yuxtapongamos a esta condición de escritura la importancia de decidirse a plasmar la palabra de una lengua aprendida como marca autoral, pues no hay por qué olvidar una lengua materna ${ }^{6}$. Así lo comenta Nene Wohlatz ${ }^{7}$ [2017]:

\footnotetext{
[el idioma materno]contiene las primeras memorias de cada uno: la intuición, la experiencia de ser comprendido, la imaginación, la posibilidad de pensar; solo podemos pensar lo que tiene palabra. Uno es su idioma. La pérdida del uso del idioma materno y el hecho de tener que empezar a vivir en un nuevo idioma constituye un gran desafío, incluso puede ser traumático. [s/p]
}

En ese impasse entre el efecto de un trauma y el intento por descubrir en lo literario el "sorbo iluminador y la frase que todo lo aclare" [138], Morábito parafrasea el conflicto sensible del acto escriturario. Reparemos en el último ensayo "El idioma materno" el hálito sensible y lírico en torno al Ilanto, que sigue a la manifestación de haber traicionado el propio idioma: "se abdica del idioma materno porque se abdica del Ilanto y se abdica del Ilanto porque sólo dejando de llorar se puede escribir" [178]. El corolario directo de ese sintomático Ilanto8 está en "Venas y arterias", donde el narrador comienza por deslindar el significado correspondiente suponiendo la presión diferencial de la sangre en venas y arterias. Esta analogía le sirve para acuñar los términos presión, neutralidad y dominio que desvían el sentido del referente centrado en la traducción. "El idioma materno" y "Venas y arterias" refrendan la pregunta de si del idioma nativo tendría la suficiente "capilaridad" para resistir

\footnotetext{
${ }^{6}$ Se entiende por lengua materna la primera lengua o idioma que la persona aprende, la cual es por adquisición; es decir, se aprende por la influencia del entorno, como por ejemplo la familia, en donde se repiten ciertos vocablos o palabras, las que van aumentando el vocabulario del niño a medida que va creciendo. Gutiérrez, Landeros, Ignacio Ariel: "Importancia del lenguaje en el contexto de la aldea global" [2010:98]

${ }^{7}$ La nota gira en torno a la traducción, los giros idiomáticos y la permanencia identitaria de la lengua materna: Roger Koza [Entrevista] "El giro lingüístico: un diálogo con Nele Wohlatz sobre el futuro perfecto". http://www.conlosojosabiertos.com/ giro-linguistico-dialogo-nele-wohlatz-futuro-perfecto/. Consulta 26/09/2017

${ }^{8}$ Alan Pauls en "El fondo de los fondos" [2008] hace comentarios interesantes acerca de lo íntimo [del Ilanto] o de la intimidad que configura un estilo, una lengua. Él opina que la intimidad está "[...] fundada en el sueño de una distancia en grado cero" [50], y que "[...] todo diario [íntimo] es un sistema de producción de cercanía, de vecindad, incluso de contemporaneidad" [50] En el 'ensayo de autor', decimos nosotros, es indudable que entre la narración y lo narrado se produce una tensión cuyas fuerzas son la distancia y la cercanía entre ese lector de sí y aquello sobre lo que lee. Una nueva variante de ese diálogo en donde estos elementos vuelven a cruzarse con más intensidad, se aprecia en Historia del llanto [2007], también de Alan Pauls.
} 
el embate del "idioma extraño" (o de "traducción" igual a "traición"). La red semántica del llanto y ahora de la sangre ejerce la deriva hacia variables expresivas de otra red semántica centrada en el conflicto del idioma materno, y al poner en contacto un idioma con otro éste se dilata al extremo de "recoger hasta la más pequeña partícula que el otro idioma vierte en el cuenco de nuestra lengua, justo como las venas $[. .$.$] que se reparta equitativamente para apaciguarlo y volverlo legible, amistoso$ y sangre de la propia sangre" [146].

El dilema del idioma materno siempre ligado al rasgo identitario del autor, connotado poéticamente por las imágenes del Ilanto y la sangre, glosa el linaje del idioma desde el primer escrito de la antología. Así, en "Scrittore, traditore", el narrador advierte que desde pequeño su intención era evitar a toda costa "estropear la palabra" y que tal esmero le sugirió desde entonces su vocación de escritor [2014:12]. Esta circunstancia anecdótica ilumina la cuestión tratada en el último ensayo, "El idioma materno", por lo que el primero y el último ensayo versan sobre la incapacidad de un lenguaje concebido como cierre conceptual o fijación del signo sobre la página. En la traducción [traición] de la lengua de origen radica el germen: "porque bien visto, se hace escritor gracias a esta traición, se aparta de la lengua madre para adoptar una lengua que no es la propia, una lengua extranjera, una lengua sin lágrimas" [178].

Ante la legitimidad o veracidad de la palabra traducida se puede revisar la perspectiva producida por el llamado giro lingüístico ${ }^{9}$, al comprender que en la traducción la equivalencia sígnica no se logra plenamente, es decir, que al final no se requiere la absoluta ratificación significativa. H.G. Gadamer en "El fin del arte" [1990] expresó lo siguiente frente al problema que conlleva autenticidad y reconocimiento ante el idioma materno y su traducción:

\footnotetext{
Oímos todas nuestras lenguas maternas y los textos de nuestra propia lengua en una plenitud, una riqueza y un resplandor que frente a la palabra y el lenguaje poético de todas las demás lenguas parecen un reconocimiento de nosotros mismos. $Y$ no obstante, cualquiera que haya vivido una temporada larga en otro mundo lingüístico sabe que a su regreso los primeros y más simples sonidos de la lengua materna nos emocionan como un reconocimiento auténtico. Con tanta más razón la palabra poética. [81]
}

Es cierto que en este específico conflicto idiomático entre el italiano y el español señalado por Morábito, late la incorporación lingüística de una nueva forma que se convertirá en estilo;

\footnotetext{
${ }^{9}$ El giro lingüístico puede definirse como una suerte de constructivismo radical, según el cual, las teorías científicas o los discursos metafísicos no descubren la realidad, sino que la crean: Esther Cohen "Reinventar el pensamiento crítico" [Percia, 2001:131]. Richard Rorty explica cómo el giro lingüístico fue propuesto como "el punto de vista de que los problemas filosóficos pueden ser resueltos (o disueltos) transformando el lenguaje o comprendiendo mejor el que utilizamos en el presente." El giro lingüístico [1990:51]
} 
curiosamente, mientras el autor enfatiza esa incomprensión como una excentricidad, ésta se convierte en familiaridad. La experiencia idiomática como lengua hablada y como escritura poética forma parte de la conciencia estilística del autor.

El idioma materno contiene no sólo el reencuentro del autor consigo mismo a través de la palabra, sino también con quienes leen su obra y captan esa mítica genialidad lingüística advertida por Pitol. Para el lector habitual, el contenido de los poemas y narraciones de Morábito se comprende por sí mismo, al unísono de sus giros idiomáticos o retóricos; sin embargo, los enunciados de tipo biográfico atraen y funcionan como una caja de resonancia que amplía el sentido referencial de su obra. Por otro lado, en tanto 'ensayo de autor', esta escritura repite esa 'gimnástica de la pluma' al estilo de Paul Valéry quien escribía y conservaba una serie de borradores -[Cuadernos (1894-1945)]como ejercicios de pensamiento en donde se perseguía o reencontraba a sí mismo, con la persistencia de una cámara fotográfica. La imagen fotográfica nos hace pensar en los retratos, en las máscaras que siempre adopta el escritor mediante un discurso que permea lo autorreferencial, metadiscursivo y metatextual ${ }^{10}$. Esta condición discursiva y argumentativa ha sido analizada en otras disciplinas. Así el psicoanalista y crítico Néstor Braunstein, en Memoria y espanto [2010], afirma que los retratos que el autor desarrolla sobre sí mismo porque los enuncia, describe y publica, forman parte de su copyright [232-33]; los retratos, afirma Braunstein, son una marca que coagula su representación, una escena del propio escenario en donde se es el libro que está escribiendo. Por analogía citamos sólo unas líneas del famoso escrito de Salvador Elizondo El grafógrafo [1999], para ampliar la percepción de un discurso autorreferencial, metadiscursivo y metatextual en donde el autor es representado a modo de autorretrato:

\footnotetext{
Escribo que escribo. Mentalmente me veo escribir que escribo y también puedo verme ver que escribo (...) También puedo imaginarme escribiendo que ya había escrito que me imaginaría escribiendo que había escrito que me imaginaba escribiendo que veo escribir que escribo. [429]
}

Los retratos figurados a propósito del idioma materno proveen además una doble máscara ya pensada como tal por Morábito, pues hablar y escribir en otro idioma es también convertirse [enmascararse] en otro:

\footnotetext{
10 Dejamos de lado estas características existentes en las escrituras híbridas como las que diferentes estudiosos han manifestado. Jaime Alazraki, por ejemplo, estudia las escrituras híbridas de Jorge Luis Borges, Octavio Paz y Julio Cortázar, quienes, con el cuento, la poesía o la novela, no dejaban de tender un puente con el ensayo [1971].
} 


\begin{abstract}
Pasar de una lengua a otra exige la mutación del ser exigen una mutación del ser [...] El escritor que escribe en una lengua extranjera [...] se convierte en otro individuo. En efecto, si escribir nos impone una máscara, escribir en otro idioma nos impone una máscara doble, o sea un nuevo rostro. Un muro se interpone entre el escritor advenedizo y la porción de su pasado que se halla vinculado con el idioma materno. [71-72]
\end{abstract}

A esa primera máscara que el autor afirma colocarse por el solo hecho de ser escritor se superpone otra, la que adopta al publicar en la lengua aprendida al tiempo que se esconde y revela más máscaras esparcidas y dilatadas a través de relatos y de anécdotas, sobre todo de infancia, que manifiestan el nacimiento de ese 'patrullaje sigiloso' para 'no estropear la palabra'. Uno de los ensayos, "Ladrón y centinela", describe la alegría de un niño que llega demasiado temprano a la escuela, cuando aún ésta no abre sus puertas, para descubrir en el amanecer y en las primeras luces la analogía sorprendente entre el crepúsculo y las primeras palabras; ambos son objetos preciosos para iluminar su mundo desde los primeros años. Hay otras historias sobre costumbres magisteriales tempranas, en "La tarea", se menciona el hábito de obligar a escribir a los niños sin levantar la cabeza, actitud que, comenta el narrador, le sirvió para inculcarle el convencimiento de que "habría que escribir bajo una constante amenaza física, en un pupitre incómodo, con la cabeza gacha y rogando por la eficacia de cada frase" [34]. En "Un sueño recurrente" [159-160], el narrador se detiene para desmenuzar la angustia causada por un sueño acerca de un examen de matemáticas: el maestro no tardará en llegar y él no tiene apunte alguno sobre la materia; el adulto reflexiona sobre si ese examen estaría relacionado con la aprobación de la persona actual [con un título de licenciatura y otro de maestría, varios libros traducidos...], o si acaso la realidad adulta es lo soñado y no al revés. Estos microrrelatos denotan las muchas búsquedas memoriosas de una infancia que expone la crisis del sujeto que escribe. Quizás, como sugiere Braunstein, es el uso de la palabra el lubricante idóneo en la génesis del sujeto desde edades tempranas [2010].

Cada anécdota relacionada con la tríada infancia, palabra y literatura, establece hilos y nudos de otra trama explicativa que asimila un cierto relato primigenio. Es decir, como en otros autores (Agamben, Ariés, De Biedma, DeMause, Lejeune y muchos más) la literatura de Morábito parece surgir del origen de su propio relato (o mythos) al recurrir al estadio infantil individual y cultural con los cuales está ligada. La "crisis" personal de Morábito o la pugna frente al idioma materno le traslada a crisis de la palabra, como si se tratara de una insatisfacción con la propia voz y del lenguaje 
inextricable, azaroso, borroso, de aquella lengua materna. Especulemos sobre las anécdotas de infancia como un espejismo ante la indiferencia del mundo. Así lo sugería María Zambrano:

[...] muchos críticos y teorizantes fueron llevados a la idea de que la poesía sea una especie de levadura de la infancia. Y bien pudiera ocurrir que la levadura sea extraída de la infancia del poeta si en esta infancia individual se encierra un don de la infancia del mundo, del alba del lenguaje; reiterada germinación de la aurora de la luz y de la palabra. [1971:228]

Recordemos que Morábito, por principio, se ha considerado a sí mismo más un poeta que un narrador, distinción que importa al destacar juicios y méritos del poema y de la prosa. De hecho, en el ensayo "Los poetas no escriben libros" advierte que

\footnotetext{
los libros, con su portentosa artificialidad, con su tratamiento espiritual intensivo, han atenuado nuestro aliento hasta lo inverosímil. Los renglones de la prosa, metódicamente alineados, proponen una respiración artificial; en cambio, los versos de la poesía, que se resisten a convertirse en renglones, alientan nuestra respiración perdida. [106]
}

Notemos en la cita la preferencia por la poesía, que encausa esa conexión entre infancia y lenguaje poético. Como acota Cabo Aseguinolaza en su erudito ensayo Infancia y modernidad literaria [2001] "la infancia es una ideación concebida [otra cosa es que lo sea efectivamente] bajo el signo de la otredad, mas al tiempo se confirma como cifra de identidad. De una identidad escindida, y se quiere; o quizá aún mejor, de una identidad desafectada que se ansía recuperar" [77]; los planteamientos acerca de la relación identitaria entre infancia-modernidad-poesía realmente no sustentan la identificación paritaria entre ambas en sentido individual y biográfico, sino cultural. A partir de estas notas es interesante que Fabio Morábito subraye su quehacer poético con la imagen de un aliento recuperado ('respiración perdida'), que no solo corresponde a sus poemas, sino a su prosa; en muchas ocasiones el escenario de situaciones, anécdotas, gestos y rituales produce en su lectura aquella sensación de recuperación de una infancia que ciertamente no tiene que responder al estatuto autobiográfico sino literario.

Enfatizamos la restitución cultural y no individual pensando en la devolución de la inocencia a la palabra, como un desprendimiento de un saber anterior o de la "cosa poética", que propicia 
una apertura de horizontes del propio creador en la búsqueda del sí mismo en un ejercicio de autorreferencia, imaginando que se aprende un lenguaje simbólico anterior a la lengua materna.

\section{Otras perspectivas que ofrece la antología}

Los 'ensayos de autor', al interesarse en la crítica de la creación y de su lectura, extienden su horizonte hacia la cultura literaria. Fabio Morábito, al identificar autores, libros y mecanismos literarios, muestra los vínculos entre él, la obra artística y la de los otros; al hacerse partícipe de la retórica del sujeto o de la autolegitimación de la escritura literaria, despliega su obra en los términos más cosmopolitas de la historiografía literaria. En esta antología encontramos señales del trayecto historiográfico literario ya citados en otros libros, el dios Pan, el Caballo de Troya, las Sirenas, Calimero, son hitos que alternan con otra mitología creada por los clásicos modernos es el caso de Don Juan, Drácula o Gregorio Samsa. Este retorno a lo clásico ya se notaba en Los pastores sin ovejas, ensayo en que el autor utiliza la alegoría del jardín bucólico-pastoril para iniciar un viaje literario de ida y vuelta: desde las tinieblas que van de Polifemo a Edipo, el caballero Ariosto, Verne el científico, Don Juan, Drácula y Hitler, y de regreso a Hermes y Filoctetes. En El idioma materno el viaje incluye alusiones semejantes, la gran diferencia es que la alegoría de un jardín bucólico se extiende a la magnitud del bosque [“Los demasiados libros"]. La vastedad literaria con la cual se enfrenta el autor precisa de la elección, debe discriminar entre libros y autores para no perderse en ellos, por eso afirma que "en medio de la espesura [...] los árboles inclinaron el tronco en la dirección debida en el momento debido y abrieron el camino a sus congéneres para transformar el bosque en una simple arboleda. Lo mismo ocurre con los libros" [19]. La selección de personajes y de obras identifica el canon que rige su obra.

Morábito incluye una serie de cuentos cuyos títulos indican una preceptiva para el lector: "Lentitud", "Nadie lee nada", "Trascender la cara", "La carrera de relevos", "Doble vidrio", “El lector

vampiro", "El libro en Ilamas", "El alma y los gestos" y "Subrayar libros", estos títulos sugieren los procesos, ardides, invenciones y certezas que todo lector enfrenta ante un relato ficción. Del lado del creador, Morábito incluye otros cuentos para considerar que la especulación y la búsqueda forman parte del destino de todo escritor, así insinúa el propio trayecto escritural en "Gregorio Samsa", "Paris", "Surcos", "Final abierto" y "Carril de acotamiento". 
Ahora bien, pensamos que el sentido referencial de El idioma materno subraya esa 'importancia libertaria del significante convertido en libro' porque los narradores de Morábito discuten la competencia y controversia entre el significante y el significado, que entran en juego en el sentido de la creación y la recepción del texto. El sentido, que con mucha frecuencia se discurre indica que, en el momento de escritura, el creador se encuentra inmerso y sorprendido del idioma que está procesando ("La capa exterior", "Un diccionario estúpido", "La soledad lingüística"). Supuesta o efectivamente, el escritor se implica en el discurso literario permitiendo que los hiatos o espacios en blanco queden abiertos a la interpretación del lector. Este tipo de relatos formulan la advertencia y la consigna de que es la palabra la que mantiene la eficacia o la determinación del significante para hacer sentido. En la libertad del significante es en donde se concentra el mensaje contenido en el libro; cada relato pone en perspectiva este peculiar problema del sentido ante la mirada del lector. Lo aparente se insinúa, pero no se resuelve, siempre permanece un resquicio incierto. Y, aunque esa incertidumbre convenga a la poesía y al cuento es importante que se conceda en el ensayo.

Ya en los cuentos compilados en Grieta de fatiga [2006], Morábito hacía énfasis en las relaciones tortuosas entre el significante y el significado. Por ejemplo, en el cuento "Las correcciones" se describe la serie de desacuerdos y protestas de la esposa de un famoso escritor, ante las enfadosas correcciones del editor. Al comparar este tipo de cuentos con los títulos contenidos en El idioma materno: "Srittore, Traditore", "La vanidad de subrayar", "Desconfianza en el oído", "La capa exterior", "El justificante perfecto" y "Al dictado", se refuerza el problema entre el significante, el significado y el sentido, porque en lo dicho/oído -escuchado/leído en el relato cuenta la primera impresión causada por la palabra elegida, que parece ya intraducible que trasciende la materia de 'lo poético', afín a "la capa exterior [...] dura como una piedra o como un idioma recién inventado" [“La capa exterior"]. En los títulos: "Un diccionario estúpido", "Taparse los oídos", "La soledad lingüística" y "Fluidez", se pondera la importancia esencial del significante que afina el oído del creador y del lector para captar el deleite de la palabra y conformarse con ello.

Al enfatizar esta cuestión en El idioma materno comprendemos su importancia en la configuración identitaria del yo y el conflicto incesante entre la lengua materna y la lengua extranjera. De cualquier forma, podemos afirmar que la identidad de quien escribe se refigura en el acto de escribir. Ésta es una cuestión que el filósofo Paul Riœur ha analizado en su obra. Él considera que los procesos identitarios o "la dimensión narrativa de la identidad" [Historia y narratividad 1999:217], 
equivale a la distancia que formula la conexión entre una vida y el relato con la mediación de éste o que, en su configuración, la identidad del escritor/narrador/personaje se procesa la existencia de un yo refigurado. La refiguración, según el filósofo, resulta del "sí mismo [que] no se conoce de modo inmediato, sino indirectamente, mediante el rodeo de toda clase de signos culturales" [1999:227]. En la identificación de uno mismo también hay un mecanismo de apropiación que conlleva a "que uno mismo se someta a las variaciones imaginativas del sí mismo" [1999:228]. Según comprendemos esta emblemática "identidad narrativa" que Riœur ha ido bosquejando en diversos textos sobre la pregunta existencial de 'quién soy', a través del experimento mental de su búsqueda, trasciende la ficción, la historiografía y el ensayo.

Las transformaciones de la identidad en el plano especulativo de la ficción y del ensayo gravitan en la constante inquietud identitaria que urde la trama del sí mismo. Repetimos la sentencia del autor "Uno se hace escritor el día que encuentra un yo postizo que viaja modestamente en el carril de acotamiento para no despertar al otro, el que ocupa el carril central" [Morábito, 2014:140]

\section{Conclusiones}

El 'ensayo de autor' como clínica de subjetividad [Percia], como indicio de que lo arbitrario en las escrituras de autor siempre requiere de una interpretación [Braunstein], o como el establecimiento de una forma de identidad narrativa [Ricoeur], no se aleja de un copyright, de una marca basada en autodesignaciones e imputaciones. El sí mismo se refigura en la palabra al enfrentarla y al divulgarla como una variante de un diálogo consigo mismo; lo concitado por la palabra transparenta los lindes de la subjetividad en la creación. Podemos considerar que en la historia de un escritor que se lee a sí mismo, como sucede en El idioma materno, se produce una tensión que comienza con la palabra, que su fuerza marca la propia distancia y cercanía entre lo que se es, se desea y se reinventa.

Los ciclos narrativos que Morábito establece en su escritura lo afirman como un sujeto no unitario sino como un yo que se desplaza y refigura en el mismo proceso cambiante de su obra. El 'ensayo de autor' es aquí un intervalo en el discurso del saber que no renuncia a la argumentación ni a la interpretación, al exponer las creencias y preferencias estéticas del sujeto, cuando se advierte que se está elucidando en coincidencia y/o en discrepancia de esa entidad que juega a ser y a no ser. En el proceso de la obra el creador explora un grado de insatisfacción, o "de fastidio" [Percia], 
que no concluye en la escritura ni en la vida. Si la escritura identitaria que convoca Morábito es una transgresión, será porque reproduce las ineludibles grietas del idioma materno.

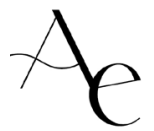

\section{BIBLIOGRAFÍA}

ALAZRAKI, Jaime: "Tres formas del ensayo contemporáneo: Borges, Paz, Cortázar", Life, 19 (1971), pp. 18-36.

BLANCHOT, Maurice: De Kafka a Kafka. Cd. de México: FCE, 2006.

BRADU, Fabiene: “Grieta de fatiga de Fabio Morábito", Letras Libres, [en línea, 31/05/2006].

BRAUNSTEIN, Néstor A.: Memoria y espanto. Cd. de México: Siglo XXI, 2010.

CABO ASEGUINOLAZA, Fernando: Infancia y modernidad literaria. Madrid: Biblioteca Nueva, 2001.

COHEN, Ester: "Reinventar el pensamiento crítico" en Marcelo Percia (Coord.), El ensayo como clínica de subjetividad, Bs.As, El Lugar Editorial, 2001, pp.119-134.

EDUCAL/CORREO DEL LIBRO: "Fabio Morábito: La patria del lenguaje": www.correodellibro.com. mx/entrevista/fabio-morabito-la-patria-del-lenguaje/ Consulta: 01/04/2015.

ELIZONDO, Salvador: "El grafógrafo" en Narrativa completa, Cd. de México: Alfaguara, 1999.

FERNÁNDEZ, Fabiola: "Fabio Morábito: Poéticas del vaivén. Extranjería, lengua y memoria" Disertación, Universidad de São Paulo. Facultad de Filosofía, Letras y Ciencias humanas departamento de Letras Modernas file://Users/maresca/Downloads/2014_ FabiolaFernandezAdechedera_VCorr.pdf. Consulta: 01/06/2017.

GADAMER, Hans. Georg: "El fin del arte" en La herencia europea. Barcelona: Península, 1990.

GUTIÉRREZ Maricel, y LANDEROS Falcón: "Importancia del lenguaje en el contexto de la aldea global", Horizontes Educacionales, 15, 1 (2010), pp. 95-107.

ILETRADO PERO CUERDO: "Escribir como un correctivo. Charlando con Fabio Morábito", iletradoperocuerdo.com/2014/10/02/escribir-como-un-correctivo-charlando-con-fabiomorabito/ Consulta: 11/05/2016. 
KOZA, Roger: [Entrevista] "El giro lingüístico: un diálogo con Nele Wohlatz sobre el futuro perfecto". http://www.conlosojosabiertos.com/giro-linguistico-dialogo-nele-wohlatz-futuro-perfecto/. Consulta 26/09/2017.

KURI, Carlos: "De la subjetividad del ensayo (problema de género) al sujeto del ensayo (problema de ensayo)" en Marcelo Percia (coord.), El ensayo como clínica de subjetividad, Bs.As.: El Lugar Editorial, 2001, pp. 99-118.

MORÁBITO, Fabio: El idioma materno. Cd. de México: Sexto Piso, 2014.

—, Grieta de Fatiga. Cd. de México: Tusquets, 2006.

ORGAMBIDE, Pedro: “Un escritor frente a su escritura” en Marcelo Percia (coord.), El ensayo como clínica de subjetividad, Bs.As.: El Lugar Editorial, 2001, pp.39-45.

PAULS, Alan: "El fondo de los fondos", Boletín del Centro de Estudios de Teoría y Crítica, Rosario: Literaria, 13/14 (2008), pp. 47-53.

— Historia del llanto. Barcelona: Anagrama, 2007.

PERCIA, Marcelo: El ensayo como clínica de subjetividad. Bs.As.: El Lugar Editorial, 2001.

PICCOLO, Francesco: Escribir es un tic. Barcelona: Ariel, 2008.

RICCEUR, Paul. "Identidad narrativa" en Historia y narratividad. Barcelona: Paidós, 1999, pp. 215-230.

RORTY, Richard: El giro lingüístico. Barcelona: Paidós, 1990.

SALAZAR, Jezreel: "Fabio Morábito, un ethos autobiográfico" http://senalc.com/2015/11/15/fabiomorabito-un-ethos-autobiografico/ Consulta: 10/06/2017.

WEINBERG, Liliana: El ensayo, entre el paraíso y el infierno. Cd. de México: UNAM/FCE, 2001.

ZAMBRANO, María: Obras reunidas. Madrid: Aguilar, 1971.

ZAMBRANO, Jessica: "Sospecho que nadie lee estas entrevistas", www.eltelegrafo.com.ec/noticias/ carton-piedra/34/fabio-morabito-sospecho-que-nadie-lee-estas-entrevistas.

Consulta: 01/06/2016. 